\title{
Phytoplankton strategies to exploit nutrients in coastal lagoons with different eutrophication status during re-oligotrophication
}

\author{
A. Leruste ${ }^{1, *}$, F. Guilhaumon ${ }^{1}$, R. De Wit ${ }^{1}$, N. Malet $^{2}$, Y. Collos ${ }^{1, \mathrm{r}}$, B. Bec $^{1}$ \\ ${ }^{1}$ MARine Biodiversity Exploitation and Conservation MARBEC, Université de Montpellier, IRD, Ifremer, CNRS. Bât. 24, \\ Place Eugène Bataillon, 34095 Montpellier cedex 5, France \\ ${ }^{2}$ Ifremer, LEPAC-Corse, ZI Furiani, Im Agostini, 20600 Bastia, France
}

\begin{abstract}
We studied a mesotrophic and a hypertrophic Mediterranean coastal lagoon, both of which had been simultaneously subjected to a nutrient input reduction for $9 \mathrm{yr}$. We compared these 2 lagoons to an oligotrophic coastal lagoon. Using bioassays comprising $24 \mathrm{~h}$ incubations with added phosphorus and/or ammonium, we investigated the response of the phytoplankton communities to nutrient enrichment during summer in terms of biomass, size class structure, abundance and growth. For nitrogen and phosphorus, we identified which nutrient limited phytoplankton growth, and what strategies of nutrient exploitation the communities adopted to cope with these limitations. Ultraphytoplankton dominated the 3 communities, but it differed in composition among the lagoons. Green algae dominated in the hypertrophic lagoon, whereas the mesotrophic lagoon presented a higher diversity of phytoplankton groups. Picocyanobacteria and small diatoms were the most abundant groups in the oligotrophic lagoon, although they accounted for less biomass than green algae. The communities of the mesotrophic and the hypertrophic lagoons strongly responded to the nutrient pulse, showing that the re-oligotrophication trajectories of these lagoons were still very vulnerable to occasional eutrophication events. On the other hand, the oligotrophic lagoon marginally responded to the enrichment, indicating its adaptation to nutrientdepleted conditions. We observed a shift along the eutrophication gradient, from a co-limitation by $\mathrm{N}$ and $\mathrm{P}$ in the oligotrophic and the mesotrophic lagoons to a single and strong $\mathrm{N}$ limitation in the hypertrophic lagoon. Each community demonstrated specific use of internal, external or recycled nutrient pools under experimentally induced limitation.
\end{abstract}

KEY WORDS: Growth rate $\cdot$ Nutrient limitation $\cdot$ Dilution experiment $\cdot$ HPLC

\section{INTRODUCTION}

Within coastal waters, lagoons are particularly vulnerable to eutrophication processes because of their restricted exchanges with the sea and their long water residence times (Pereira Coutinho et al. 2012). Eutrophication is often caused by nutrient overenrichment, which stimulates primary producers and strongly impacts the composition of the autotrophic compartment (De Jonge \& Elliott 2001). It notably modifies the competition between functional groups

*Corresponding author: a.lerustecalpena@gmail.com

${ }^{ \pm}$Deceased depending on their resource acquisition strategies and their growth abilities (Paerl et al. 2003). Hence, availability of phosphorus and nitrogen constitutes the main abiotic factor controlling phytoplankton growth, biomass and community composition in shallow coastal lagoons (Collos et al. 2004) and thus represents an important aspect for eutrophication management (Domingues et al. 2011, Gallegos 2014).

The loss of ecosystem services due to the eutrophication of aquatic ecosystems has been a strong impetus for setting a target of reversing eutrophication,

() The authors 2019. Open Access under Creative Commons by Attribution Licence. Use, distribution and reproduction are unrestricted. Authors and original publication must be credited. 
which is also in agreement with the objectives of the Water Framework Directive (WFD, 2000/60/EC) (Cartaxana et al. 2009). To improve the ecological status of eutrophic aquatic systems and initiate their ecological restoration, nutrient inputs must be reduced. Some freshwater systems have been submitted to reoligotrophication processes since the 1970s (Jeppesen et al. 2005, 2007, Van Donk et al. 2008). However, ecological restoration is a very complex and variable process, which often requires a long time to be successful (de Jonge \& de Jong 2002). Indeed, several lakes showed hysteresis during their re-oligotrophication, related to persistent nutrients loads. These nutrients originate from the remobilization of organic material in the sediment (Jeppesen et al. 2005, Phillips et al. 2005), or from outside due to an insufficient reduction of external loads (Van Donk et al. 2008). Thus, to be effective, nutrient management of eutrophic waterbodies requires understanding the relationships between primary production and nutrient loads, especially from external and recycled sources (Domingues et al. 2011, Wood \& Bukaveckas 2014). For several coastal waters such as lagoons, the responses to ecological restoration through their re-oligotrophication have been assessed (Collos et al. 2009, Leruste et al. 2016). Re-oligotrophication first impacts phytoplankton communities, inducing some functional responses. It results in an increase in nutrient limitation (Nixon 2009), which is one of the keystone drivers of phytoplankton growth and composition (Cloern 2001, Crossetti \& Bicudo 2005). Similar to eutrophication, reoligotrophication particularly affects the size structure of phytoplankton communities (Ruggiu et al. 1998, Collos et al. 2009, Kamenir \& Morabito 2009). However, studies of re-oligotrophication are more scarce than those of eutrophication, and their results are quite complex to interpret due to the intrinsic complexity of these ecosystems. There is thus a strong need for studies of re-oligotrophication (Domingues et al. 2011), since this process is still poorly documented and understood (Phillips et al. 2005).

In the coastal lagoons along the French Mediterranean coastline, phytoplankton nutrient limitation is variable, with consequences for their ecosystem functioning. Particularly, along the eutrophication gradient, a shift from phosphorus to nitrogen limitation with increasing eutrophication has been described (Souchu et al. 2010). Among the French Mediterranean coastal lagoons, a complex of 8 lagoons was submitted to an intense eutrophication process since the 1960s, mainly due to the indirect discharge of effluents from the Montpellier city district wastewater treatment plant. Related to the distance from this ma- jor point source, a eutrophication gradient formed along the lagoon complex, from mesotrophic in the southwest to hypertrophic in the northeast. Picophytoplankton, which is highly competitive to nutrient pulses, dominated the autotrophic communities of these lagoons (Bec et al. 2011). Since 2005, the lagoon complex has been submitted to a drastic reduction of anthropogenic $\mathrm{P}$ and $\mathrm{N}$ inputs, leading to the beginning of a re-oligotrophication process. This new dynamic has driven strong responses of phytoplankton communities, reflected by a sharp decrease in phytoplankton biomass and picoeukaryote abundance. It has also triggered drastic changes in community composition related to the functional responses of the different species. The outcome was variable among lagoons, and was dependent on their eutrophication status before the start of the nutrient input reduction (Leruste et al. 2016). Hence, studying stations in different lagoons in this complex offered the unique advantage that, while the period of their re-oligotrophication process was exactly the same, they differed in eutrophic status before the start of this process in 2005. The impact of the previous trophic state on phytoplankton to nutrient conditions during the re-oligotrophication process could thus be assessed.

It is important to understand how phytoplankton functionally respond to nutrient availability, particularly in terms of growth and community composition. This knowledge will in turn help us to understand the result of eutrophication management, and to predict time scales of re-oligotrophication processes (Domingues et al. 2015). Therefore, we formulated 3 main questions: (1) How vulnerable are these lagoons during the re-oligotrophication process to a nutrient pulse? More specifically, we asked: Which organisms within phytoplankton assemblages respond in the short term to a nutrient pulse, depending on the nutrient, and how do they respond? (2) Which nutrients limit the growth of phytoplankton assemblages during re-oligotrophication processes in lagoons? (3) What strategies of resource use can phytoplankton assemblages employ to cope with an experimentally induced nutrient limitation? Specifically: Which nutrient sources are preferentially used, considering internal, external and recycled pools?

To examine these questions, we conducted a study on 2 lagoons from the complex that strongly differed in their eutrophication status before the start of the re-oligotrophication process and presently still show differences. For comparison, we also selected an oligotrophic lagoon which has remained in a good ecological state over the past 2 decades. During the summer of 2014, we experimentally incubated phyto- 
plankton communities from these 3 lagoons with an added nutrient enrichment, under in situ light and temperature conditions. The full nutrient enrichments allowed us to assess the reactivity of the phytoplankton assemblages to a nutrient pulse. Moreover, we also explored the vulnerability of the re-oligotrophication process to a nutrient pulse. Using the 'All minus one' technique, we induced nitrogen and phosphorus limitations to understand phytoplankton strategies to offset depleted conditions (Andersen et al. 1991).

\section{MATERIALS AND METHODS}

\subsection{Study sites and sampling procedures}

Along the French Mediterranean coastline, the mesotrophic north Ingril (IN) and hypertrophic west Méjean (MW) lagoons are located at the southwest and the northeast of the Palavas lagoon complex. They represent in this complex the lesser and the mostly eutrophied lagoons, respectively (Fig. 1). Both lagoons are separated from the sea by the Rhône-toSète canal, and hydraulic exchanges with the sea are therefore indirect via this canal only. Both lagoons were exposed to nutrient over-enrichment from the 1960s to 2005 and have followed a re-oligotrophication trajectory since December 2005 (Leruste et al. 2016). However, their benthic nutrient stocks still represent a significant internal source of nutrients (Souchu et al. 2010). The phytoplankton communities of these

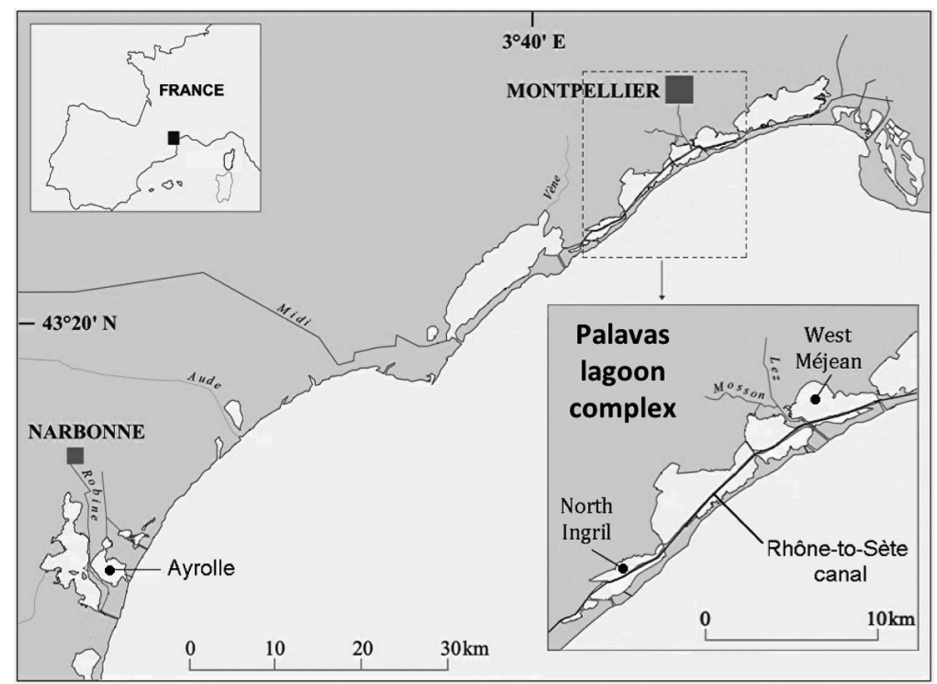

Fig. 1. Sampling stations in Ayrolle (AYR, oligotrophic), north Ingril (IN, mesotrophic), west Méjean (MW, hypertrophic) lagoons in southern France
2 lagoons were compared to those of a lagoon that has virtually not been impacted by eutrophication: the Ayrolle lagoon (AYR) (Fig. 1). This oligotrophic lagoon has a small watershed $\left(104 \mathrm{~km}^{2}\right)$ without urbanization. AYR is connected to the sea by a natural inlet in the southeast, while the 2 selected lagoons from the Palavas complex are not directly connected to the sea, but communicate indirectly through the Rhône-to-Sète canal and adjacent lagoons. Since the start of the monitoring program in 1998, the AYR lagoon has been characterized by a good ecological state, low nutrient concentrations and low phytoplankton biomass (Souchu et al. 2010).

Experiments were carried out from 25 August to 4 September 2014. In each lagoon, 701 of water prefiltered through $1000 \mu \mathrm{m}$ mesh to remove larger debris without removing zooplankton or larger phytoplankton cells (Collos et al. 2005) were sampled in sub-surface $(20 \mathrm{~cm}$ depth) between 08:30 and 11:00 $\mathrm{h}$ and kept in the dark. At the sampling stations, salinity and temperature were measured with a conductivity meter (Cond 3110 Set 2) at $20 \mathrm{~cm}$ depth.

Upon return to the laboratory, water samples were homogenized by gentle shaking and were then aliquoted. Two volumes of $80 \mathrm{ml}$ of water were sampled in $100 \mathrm{ml}$ polypropylene bottles, prewashed with $1 \mathrm{~mol} \mathrm{l}^{-1} \mathrm{HCl}$ and rinsed 3 times with milli-Q water, to measure the concentrations of $\mathrm{NH}_{4}{ }^{+}, \mathrm{PO}_{4}{ }^{3-}, \mathrm{NO}_{3}{ }^{-}$, $\mathrm{NO}_{2}{ }^{-}$, total nitrogen (TN) and total phosphorus (TP) $(\mu \mathrm{M})$. Concentrations of dissolved inorganic nutrients $\left(\mathrm{PO}_{4}{ }^{3-}, \mathrm{NO}_{3}{ }^{-}, \mathrm{NO}_{2}{ }^{-}\right)$were obtained by segmented flow automatic colorimetry (Raimbault et al. 1990, Aminot \& Kérouel 2004, 2007), and ammonium concentrations were obtained using fluorescence (Holmes et al. 1999).

\subsection{Size class structure and phytoplankton community composition}

Chlorophyll a ( $\mathrm{chl}$ a) concentrations were used as a proxy for phytoplankton biomass. Phytoplankton pigment analysis and biomass measurement were performed on size-fractioned water to assess the contribution of 3 different size classes, i.e. ultraphytoplankton $(<5 \mu \mathrm{m})$, nanophytoplankton $(5-20 \mu \mathrm{m})$ and microphytoplankton $(>20 \mu \mathrm{m})$ to the total phytoplankton biomass, and phytoplankton community compositions for each size class. To obtain size-fractioned water, triplicates of water samples were filtered on nylon filtration tissue with $20 \mu \mathrm{m}$ and $5 \mu \mathrm{m}$ meshes to de- 
termine the contribution of nanophytoplankton and ultraphytoplankton to total phytoplankton biomass. Known volumes of water samples and size-fractioned water aliquots were filtered on Whatman GF/F membranes ( $25 \mathrm{~mm}$ diameter and $0.7 \mu \mathrm{m}$ porosity) and stored at $-20^{\circ} \mathrm{C}$. The volumes chosen for the filtrations depended on phytoplankton biomasses and were maximally $100 \mathrm{ml}$. The filters were ground in acetone $(90 \%)$ and extracted during $24 \mathrm{~h}$ in the dark at $4{ }^{\circ} \mathrm{C}$. Pigments were measured by spectrofluorometry (Neveux \& Lantoine 1993). Concentrations are expressed in $\mu \mathrm{g} \mathrm{l}^{-1}$.

The biomass of microphytoplankton was obtained by subtracting chl a concentration of size-fractioned water filtered on $20 \mu \mathrm{m}$ from the total chl a concentration. The biomass of nanophytoplankton was obtained by subtracting the chl a concentration of the size-fractioned water filtered on $5 \mu \mathrm{m}$ from that of the water filtered on $20 \mu \mathrm{m}$, and the biomass of ultraphytoplankton was obtained from the chl a concentration of the size-fractioned water filtered on $5 \mu \mathrm{m}$.

Chemotaxonomic analysis using HPLC estimated phytoplankton taxonomic diversity in each size class (Leruste et al. 2015). Triplicates of size-fractioned water samples (150-2000 ml, depending on biomass densities) were filtered on Whatman GF/F membranes (47 mm diameter), and stored at $-80^{\circ} \mathrm{C}$ prior to analysis. Pigments were extracted during $1 \mathrm{~h}$ with $5 \mathrm{ml}$ of a mix acetone/methanol/water. Pigment analysis allowed the estimation of some major algal group biomasses using concentrations of pigment markers: heterokonts such as fucoxanthin-rich diatoms using fucoxanthin, dinophytes using peridinin, prasinophytes using prasinoxanthin, cryptophytes using alloxanthin, haptophytes using 19'but-fucoxanthin and 19'hex-fucoxanthin, green algae using chl $b$, lutein, violaxanthin, neoxanthin and zeaxanthin. Zeaxanthin pigment can also indicate cyanobacteria occurrence, although diatoxanthine can indicate the presence of euglenophytes, and violaxanthin can indicate the presence of chrysophytes (Roy et al. 2011).

Flow cytometry and optical microscopy complemented the description of community composition inferred from the HPLC (Sherrard et al. 2006, Paerl et al. 2007), particularly to resolve the zeaxanthin signal that corresponds both to green algae and cyanobacteria. Flow cytometry refined the HPLC results for ultraphytoplankton and especially cyanobacteria, by measuring abundances of cells $<5 \mu \mathrm{m}$, (FACSCalibur, Becton Dickinson) (Bec et al. 2011). Cyanobacteria and eukaryotic phytoplankton cells (Peuk: picoeukaryotes $<3 \mu \mathrm{m}$; and large ultra: ultraphytoplankton cells between 3 and $5 \mu \mathrm{m}$ ) were distin- guished on the basis of light diffraction (forward scatter, related to cell size) and red fluorescence emissions (chl $a$, wavelength $>650 \mathrm{~nm}$ ), using beads for size calibration. Populations of coccoid cyanobacteria were identified by their orange fluorescence emission, and phycoerythrin-rich picocyanobacteria (PEcyan) were distinguished from phycocyanin-rich picocyanobacteria (PC-cyan) (Bec et al. 2011). Optical microscopy observations complemented HPLC results for nano- and microphytoplankton, by measuring abundances and taxonomic diversity of cells $>5 \mu \mathrm{m}$. Triplicates of 11 samples fixed with formaldehyde (5\% final concentration) were stored in the dark prior to analysis. Because of weak phytoplankton biomasses in the oligotrophic lagoon, a modified Utermöhl protocol was used (Leruste et al. 2018). Taxonomic resolution was realized at the species level whenever possible, and verified according to the World Register of Marine Species (www.marinespecies.org/) and the scientific literature.

\subsection{Maximal growth and mortality rates}

Phytoplankton maximal growth rates were measured by dilution experiments according to Landry \& Hassett (1982). Five dilutions containing 9, 17, 43, 74 and $100 \%$ of sample in filtered lagoon water $(0.2 \mu \mathrm{m}$ Suporcap cartridges, Pall-Gelman, previously rinsed with 11 of deionized water and sample water) were carried out in duplicate. The 5 duplicates were incubated in 11 polycarbonate bottles previously washed with $10 \% \mathrm{HCl}$ and rinsed 3 times with milli-Q water (Leruste et al. 2019). Before incubation, the bottles containing the different dilutions of sample received an enrichment based on $\mathrm{f}$ culture medium (Guillard \& Ryther 1962), containing vitamins, silica, trace metals, nitrogen and phosphorus $\left(\mathrm{NaH}_{2} \mathrm{PO}_{4}\right.$, final concentration $0.8 \mu \mathrm{M})$. The nitrogen was provided as ammonium (20 $\mathrm{\mu M}$ final concentration), assuming that this is the predominant nitrogen form in these lagoons during summer, mostly derived from remineralization processes in the sediment (Collos et al. 2003, Serpa et al. 2007) and in view of previous observations on the lagoons from the Palavas complex and its surroundings (Ifremer 2009). This quantity of nitrogen was chosen to avoid phytoplankton growth limitation, previously observed at $10 \mu \mathrm{M}$ in another lagoon from the same region (Bec et al. 2005). Two bottles of sample without dilution and enrichment were incubated as controls. Bottles were incubated for $24 \mathrm{~h}$ in Thau lagoon water under in situ temperature and light conditions at $60 \mathrm{~cm}$ depth. 
After $24 \mathrm{~h}$ incubation, chl a concentrations of total, micro-, nano- and ultraphytoplankton were measured in each bottle. The temporal changes of chl a concentration of each fraction after $t=24 \mathrm{~h}$ were used to estimate their apparent growth rate $k(x)$ for each dilution $(x)(x=1$ for undiluted sample, and $x=0$ for infinite dilution). For the enrichments, the results were fitted to the linear Eq. (1) (Landry \& Hassett 1982):

$$
k(x)=\mu_{\max }-g x
$$

where $x$ is the dilution factor, $k(x)$ is the apparent specific growth rate, $\mu_{\max }$ is the maximum growth rate, and $g$ is the specific mortality rate assumed to correspond to grazing (all rates expressed as $\mathrm{d}^{-1}$ ). Hence, linear regression of the apparent growth rate $(k)$ versus dilution factor $(x)$ was used to obtain the maximum growth rate $\left(\mu_{\max }\right)$ as the $y$-axis intercept, and the grazing rate $(g)$ as the slope of the linear regression. Phytoplankton growth rate in incubations without added nutrient $\left(\mu_{0}\right)$ was subsequently extrapolated by adding $g$ (estimated for nutrient-enriched series, see above) to the apparent growth rate $\left(k_{0}\right)$ estimated for undiluted unenriched treatments, assuming that grazing was not impacted by the enrichment. The $\mu_{0}: \mu_{\max }$ ratio assessed the impact of inorganic nutrient enrichment on growth and estimated the nutrient sufficiency for phytoplankton growth (Landry \& Hassett 1982, Landry et al. 1998).

\subsection{Nutrient limitation and resource use}

To assess the physiological nutrient limitation of phytoplankton, an 'All minus one' experiment was combined with the dilution technique (Landry \& Hassett 1982). It consisted of selectively enriching 2 dilution series leaving out either nitrogen or phosphorus (Andersen et al. 1991). We assumed that specific grazing rates $(g)$ were not affected by leaving out one of the nutrients, and can be estimated using the complete enrichment series. All bottles, i.e. both full and partial enrichments, were incubated together for 24 hours.

To identify which nutrient sources were used for phytoplankton growth during experimentally induced nutrient limitation, and to estimate their relative contributions, we considered 3 potential sources: (1) an external source comprising the dissolved nutrients in the water at the beginning of incubation; (2) internal nutrient pools present in the cells at the start of incubation; and (3) nutrients supplied by recycling through grazing, considering excretion, egestion and 'sloppy feeding' (release of organic matter during physical phytoplankton cell breakage, followed by microbial degradation). Hence, the potential biomass production can be divided into $C_{\mathrm{E}}(t)$ from the external nutrient pool, $C_{\mathrm{I}}(t)$ from internal nutrient reserves and $C_{R}(t)$ from the recycled nutrients. The external nutrient source is not affected by the dilution, while internal reserves are proportionally reduced. Grazing is reduced by a factor $x$, reducing recycled nutrient supply by the same proportion. Assuming that the amount of recycled nutrient is proportional to the amount of consumed food, the potential growth yield can be expressed as a function of the dilution factor:

$$
\Delta C(x, t)=\Delta C_{\mathrm{R}}(t) x^{2}+\Delta C_{\mathrm{I}}(t) x+\Delta C_{\mathrm{E}}(t)
$$

Accepting Eq. (2), and assuming that initial biomass in each dilution experiment was identical to biomass of the undiluted sample, reduced by the dilution factor $(x)$, i.e. $C(x, 0)=x . C(1,0)$, the apparent growth rate $k(x)$ can be expressed by:

$$
k(x)=\frac{1}{t} \ln \left(1+\frac{\Delta C_{\mathrm{R}}(t) x^{2}+\Delta C_{\mathrm{I}}(t) x+\Delta C_{\mathrm{E}}(t)}{x C(1,0)}\right)
$$

Introducing the potential production coefficient due to each nutrient source $(Z)$ by $K_{Z}=\frac{\Delta C_{Z}(x, t)}{C(1,0)}$, Eq. (3) can be re-expressed with production coefficients:

$$
k(x)=\frac{1}{t} \ln \left(1+K_{\mathrm{R}} x+K_{\mathrm{I}}+K_{\mathrm{E}} X^{-1}\right)
$$

where $k(x)$ is the apparent phytoplankton growth rate at dilution $x$, and $K_{\mathrm{E}}, K_{\mathrm{I}}$ and $K_{\mathrm{R}}$ are the potential production coefficients of the 3 different nutrient pools. These coefficients represent the relative yields of external, internal and remineralized nutrients, respectively. The values of $K_{\mathrm{E}}, K_{\mathrm{I}}$ and $K_{\mathrm{R}}$ can be estimated by fitting Eq. (4) to estimate $k(x)$ by a non-linear regression method. To estimate parameters $K_{\mathrm{R}}$, $K_{\mathrm{I}}$ and $K_{\mathrm{E}}$ by multiple linear regressions, Eq. (4) can be antiloged on each side, giving the following expression:

$$
\exp (k(x) t)-1=K_{\mathrm{R}} x+K_{\mathrm{I}}+K_{\mathrm{E}} x^{-1}
$$

with $x$ and $x^{-1}$ as independent variables and $\exp (k(x)$ t) -1 as the dependent variable.

According to these equations, Andersen et al. (1991) showed how mean growth rate expressed the contribution of each nutrient source. To estimate the $\mathrm{N}$ and/or P limitation controlling the growth, the $Q$ ratio between maximal growth rate in non-limiting nutrient conditions $\left(\mu_{\max }\right)$ and growth rate under $\mathrm{N}$ or P limitation ( $\mu_{-\mathrm{N}}$ or $\mu_{-\mathrm{P}}$, respectively) was calculated and is given as $Q_{\mathrm{N}}$ or $Q_{\mathrm{P}}$. 


\subsection{Statistical analysis}

Data analysis was performed with R (R Core Team 2013). To estimate the maximal growth rate and the grazing rate for the total phytoplankton and the 3 size classes, mixed-effect multiple regression analyses were performed with apparent growth rate for each dilution as the dependent variable. Several equations resulting in the combination of explanatory variables of Eq. (1) were fitted with the 'Imer' function from the 'Ime4' library (version 1.1-10, Bates et al. 2015). All combinations were considered using the 'dredge' function of the 'MuMIn' package (Bartón 2013). Model selection was based on parsimony using the small-sample corrected Akaike's information criterion $\left(\mathrm{AIC}_{\mathrm{c}}\right)$. However, the linear model was selected as it allows calculating $\mu_{\max }$ and $g$ according to Eq. (1) (Landry \& Hassett 1982). To check whether this selection was justified, we calculated the difference between the $\mathrm{AIC}_{\mathrm{c}}$ of this model and the one having the lowest $\mathrm{AIC}_{\mathrm{c}}$ to obtain a $\mathrm{AIC}_{\mathrm{c}}$ value. The linear model was accepted only for $\mathrm{AIC}_{\mathrm{c}}<2$, and we concluded that it does not statistically make sense to calculate $\mu_{\max }$ and $g$ for $\mathrm{AIC}_{\mathrm{c}}>2$ (Burnham \& Anderson 2004).

To estimate the contribution of the 3 different nutrient sources to growth during experimentally induced nutrient limitation in the 'All minus one' incubations, we estimated the $K_{\mathrm{I}}, K_{\mathrm{E}}$ and $K_{\mathrm{R}}$ coefficients reflecting internal, external or recycled sources, respectively. Therefore, we used mixed-effect multiple linear regressions according to Eq. (5). These calculations were performed for total phytoplankton and separately for the 3 size classes. Based on Eq. (5), several models using combinations of the explanatory variables were fitted with the 'Imer' function. To identify the best model (best combinations of the 3 resource coefficients), $\mathrm{AIC}_{\mathrm{c}}$ was used to select the most parsimonious model. We then estimated the proportion of biomass produced from these 3 sources, by multiplying initial biomasses with the 3 coefficients (Andersen et al. 1991).

\section{RESULTS}

\subsection{Environmental parameters reflecting the eutrophication status of the lagoons}

Environmental parameters and chl a concentrations for the 3 lagoons during sampling are presented in Table 1. Salinity was higher than the seawater salinity in the mesotrophic IN lagoon (41), close to that of the seawater in the hypertrophic MW lagoon (37), and lower (31) in the oligotrophic AYR lagoon. Temperatures were comparable among lagoons $\left(21-23^{\circ} \mathrm{C}\right)$. Dissolved inorganic nitrogen concentrations were lower than $1.5 \mu \mathrm{M}$ in the 3 lagoons, and mainly comprised ammonium. Chl a, TP and phosphate concentrations reflected the eutrophication gradient displayed by the lagoons. A remarkably high phosphate concentration $(2.5 \mu \mathrm{M})$ was observed in the hypertrophic MW lagoon. TN concentrations were comparable for the oligotrophic AYR and the mesotrophic IN lagoons (around $30 \mu \mathrm{M}$ ), and 4-fold higher $(123 \mu \mathrm{M})$ in the hypertrophic MW lagoon. This resulted in a strong decrease of the TN:TP ratio along the eutrophication gradient, from 72 (AYR) to 14 (MW).

\subsection{Composition of phytoplankton communities}

Phytoplankton communities in the 3 lagoons were dominated by ultraphytoplankton $<5 \mu \mathrm{m}$. This represented 87,63 and $84 \%$ of the total chl a concentrations in the oligo-, meso- and hypertrophic lagoons, respectively (Fig. 2). However, the composition of this major size class changed among lagoons. Green algae dominated the biomass of the ultraphytoplankton of the oligo- and the hypertrophic lagoons, representing 44.5 and $55.3 \%$ of the pool of pigments (Fig. 3). Among green algae, Chlorella-like cells dominated in the hypertrophic MW lagoon. Green algae and cryptophytes dominated the ultraphytoplankton of the mesotrophic IN lagoon, reaching 38.2 and $37.7 \%$ of the pigment concentrations. Cryptophytes were also

Table 1. Environmental parameters and phytoplankton biomasses expressed as chlorophyll a (chl a) concentration in the 3 lagoons during sampling in summer 2014. Chl a concentrations are expressed as mean and standard deviation of triplicates. Lagoons (see Fig. 1) are AYR: Ayrolle (oligotrophic), IN: north Ingril (mesotrophic), MW: west Méjean (hypertrophic). TN: total nitrogen, DIN: dissolved inorganic nitrogen, TP: total phosphorus. Dates are given as d/mo/yr

\begin{tabular}{|c|c|c|c|c|c|c|c|c|c|c|c|c|}
\hline \multirow[t]{2}{*}{ Lagoon } & \multirow[t]{2}{*}{ Date } & \multirow{2}{*}{$\begin{array}{l}\text { Temp } \\
\left({ }^{\circ} \mathrm{C}\right)\end{array}$} & \multirow[t]{2}{*}{ Salinity } & \multicolumn{7}{|c|}{-Nutrient $(\mu \mathrm{M})$} & \multirow{2}{*}{$\begin{array}{l}\text { Total chl a } \\
\quad\left(\mu \mathrm{g} \mathrm{l}^{-1}\right)\end{array}$} & \multirow[t]{2}{*}{ TN:TP } \\
\hline & & & & $\mathrm{TN}$ & $\mathrm{NH}_{4}$ & $\mathrm{NO}_{3}$ & $\mathrm{NO}_{2}$ & DIN & $\mathrm{TP}$ & $\mathrm{PO}_{4}$ & & \\
\hline AYR & 03/09/14 & 21.0 & 30.9 & 32.5 & 0.62 & 0.00 & 0.07 & 0.69 & 0.45 & 0.12 & $0.23 \pm 0.01$ & 72.2 \\
\hline IN & $25 / 08 / 14$ & 20.8 & 41.5 & 28.2 & 0.99 & 0.15 & 0.07 & 1.21 & 0.89 & 0.21 & $0.98 \pm 0.04$ & 31.7 \\
\hline MW & $27 / 08 / 14$ & 23.2 & 36.6 & 123 & 0.68 & 0.00 & 0.37 & 1.05 & 8.72 & 2.48 & $36.1 \pm 0.68$ & 14.1 \\
\hline
\end{tabular}




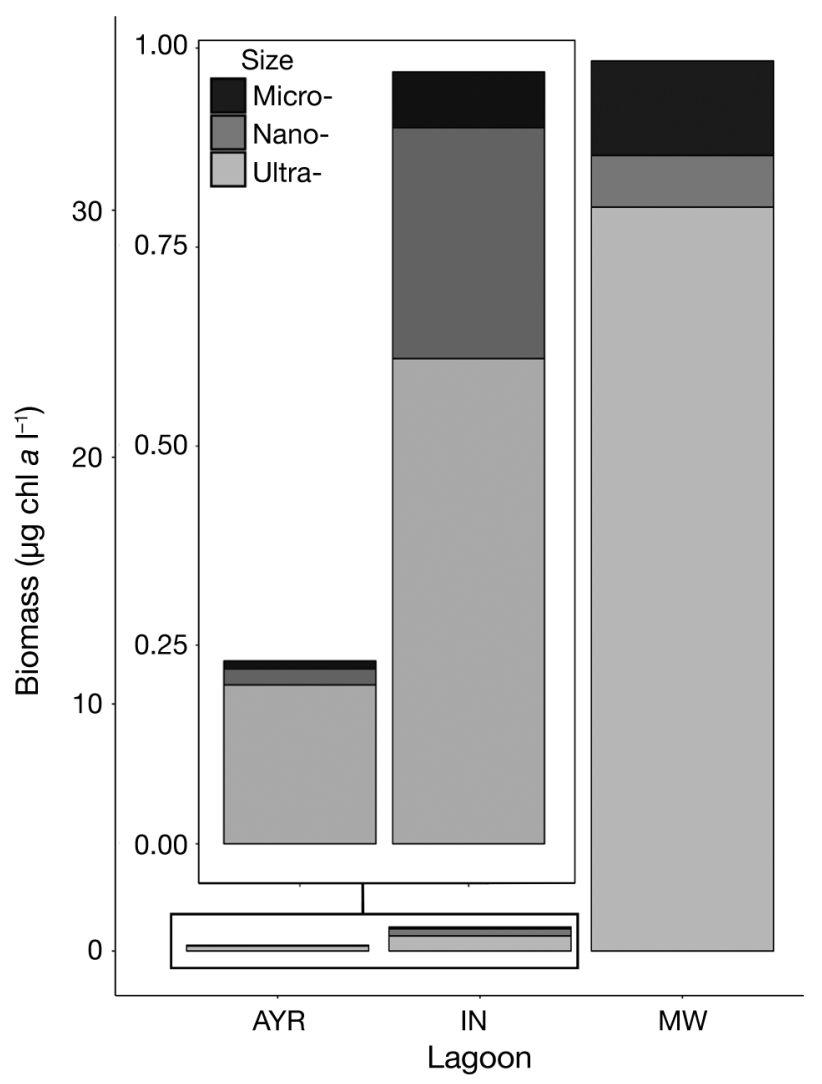

Fig. 2. Contribution of ultraphytoplankton $(<5 \mu \mathrm{m}$, light grey), nanophytoplankton (5-20 $\mu \mathrm{m}$, grey) and microphytoplankton $(>20 \mu \mathrm{m}$, dark grey) to the total biomass, in the oligo- (AYR), meso- (IN) and hypertrophic (MW) lagoons (see Fig. 1) in summer 2014

well represented in the ultraphytoplankton of the oligotrophic AYR lagoon, with alloxanthin representing $19.4 \%$ of the pigments of this fraction. Small-size fucoxanthin-rich diatoms also composed the ultraphytoplankton of the 3 lagoons, with fucoxanthin repre- senting $19.7,12.1$ and $16.6 \%$ of the pool of pigments in the oligo-, meso- and hypertrophic lagoons, respectively. Ultraphytoplankton also comprised picocyanobacteria, their biomass proportion reaching $7.6 \%$ in the mesotrophic, $12.6 \%$ in the oligotrophic and $19.7 \%$ in the hypertrophic lagoons. In terms of abundance, PC-cyan numerically dominated the ultraphytoplankton of the oligotrophic lagoon (Peuk: $11.9 \%$, PC-cyan: $76.5 \%$ ), while Peuk dominated those of the Palavas lagoons (IN and MW) (Fig. 4). The numerical dominance of Peuk was particularly marked in the hypertrophic MW lagoon, representing $68 \%$ of total cell counts. Moreover, PC-cyan were also abundant in the hypertrophic lagoon, representing $30.6 \%$ of the cell counts. In contrast, PE-cyan were only detected in the mesotrophic lagoon, reaching $2.3 \%$ of the ultraphytoplankton abundance (Fig. 4).

Nano- and microphytoplankton compositions also changed among lagoons. The hypertrophic MW lagoon still displayed the highest proportion of green algae, representing 64.7 and $61.6 \%$ of the pigment pools for nano- and microphytoplankton. Although peridinin was never detected in the hypertrophic lagoon, dinophyte abundances, proportions and richness were high according to microscopic observations. Moreover, the observed taxa, including Dinophysiales (Oxyphysis oxitoxoides Kofoid [1926]), Gonyaulacales (Alexandrium sp., Gonyaulax spinifera [Claparède \& Lachmann] Diesing [1866]), Gymnodiniales (Gymnodinium sanguineum Hirasaka [1922]), Peridiniales (Heterocapsa minima Pomroy [1989], H. niei [Loeblich III] Morrill \& Loeblich III [1981], Peridinium quinquecorne Abé [1927], Kryptoperidinium foliaceum Lindemann [1924]) and Prorocentrales (Prorocentrum micans Ehrenberg [1834]), were most likely mostly heterotrophic (lacking chl a).

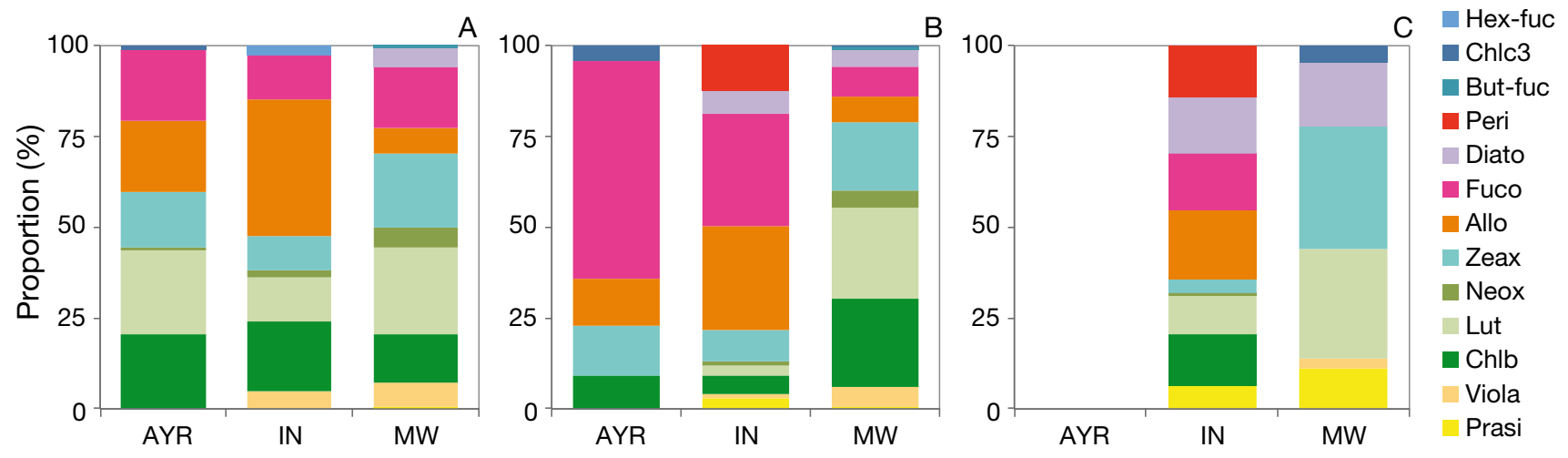

Fig. 3. Relative proportions of pigment biomarkers of phytoplankton communities in oligo- (AYR), meso- (IN) and hypertrophic (MW) lagoons (see Fig. 1), detailed for (A) ultra-, (B) nano- and (C) microphytoplankton. Pigment concentration of the microphytoplankton of AYR was below the detection limits. Hex-fuc: 19'hex-fucoxanthin, Chlc3: chlorophyll c3, But-fuc: 19'butfucoxanthin, Peri: peridinin, Diato: diatoxanthine, Fuco: fucoxanthin, Allo: alloxanthin, Zeax: zeaxanthin, Neox: neoxanthin, Lut: lutein, Chlb: chlorophyll $b$, Viola: violaxanthin, Prasi: prasinoxanthin 

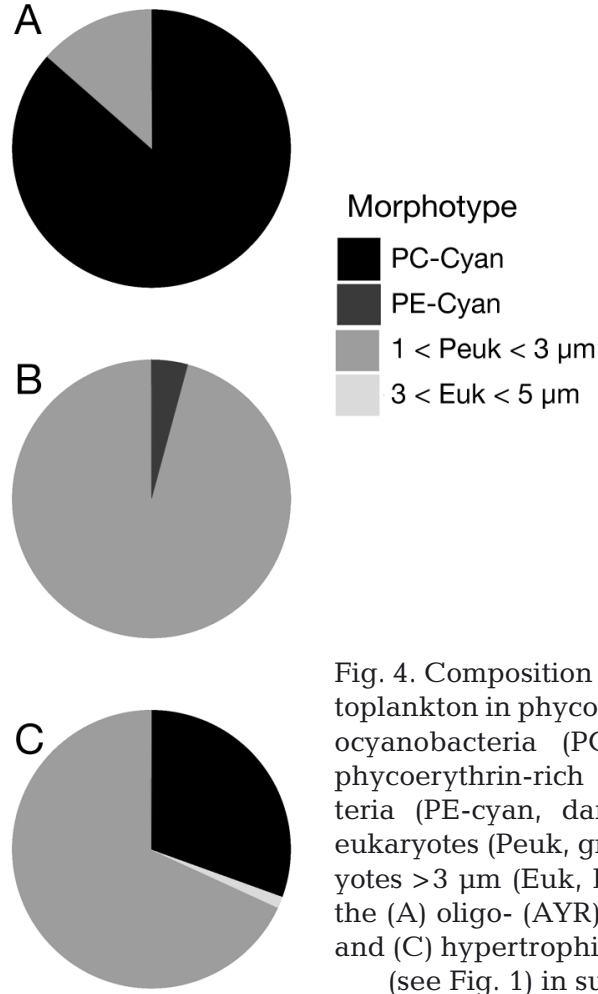

Fig. 4. Composition of the ultraphytoplankton in phycocyanin-rich picocyanobacteria (PC-cyan, black), phycoerythrin-rich picocyanobacteria (PE-cyan, dark grey), picoeukaryotes (Peuk, grey), and eukaryotes $>3 \mu \mathrm{m}$ (Euk, light grey) from the (A) oligo- (AYR), (B) meso- (IN) and (C) hypertrophic (MW) lagoons (see Fig. 1) in summer 2014

\subsection{Growth and mortality rate without nutrient enrichment}

Growth and mortality rate estimates based on chl a concentrations are indicated in Table 2. Without enrichment, the total phytoplankton of the oligotrophic lagoon exhibited a growth rate $\left(\mu_{0}\right)$ of $1.20 \mathrm{~d}^{-1}$. In the mesotrophic lagoon, the total biomass strongly decreased during the incubation without enrichment, which impeded the calculation of a positive $\mu_{0}$. In the hypertrophic lagoon, no meaningful rates could be estimated for the total phytoplankton using the linear model, the trend of the relationship between apparent growth rate and dilution factor being non-linear (see Fig. S1C in the Supplement at www. int-res.com/articles/suppl/a083p131_supp.pdf). However, by dividing the community into size classes, we were able to calculate specific growth and grazing rates for the microphytoplankton and ultraphytoplankton in all 3 lagoons (Table 2).

The microphytoplankton of the oligotrophic lagoon, mainly represented by diatom species, exhibited the highest $\mu_{0}$, reaching $3.95 \mathrm{~d}^{-1}$. Conversely, the ultraphytoplankton, which dominated the community and
The mesotrophic lagoon exhibited the highest pigment diversity both for nano- and microphytoplankton (Fig. 3). These fractions also displayed nearly even proportions of different taxonomic groups among dinophytes (peridinin), green algae, fucoxanthinrich diatoms and cryptophytes (alloxanthin). This was the only lagoon to exhibit peridinin, representing $12.4 \%$ of the pigment pool for nanophytoplankton and $14.2 \%$ for microphytoplankton. In the oligotrophic AYR lagoon, diatoms $\left(2.3 \times 10^{4}{\left.\text { cells } ~^{-1}\right)}^{-1}\right.$ represented by several Chaetoceros species and benthic species such as Licmophora sp. dominated the nanoand microphytoplankton. This dominance was illustrated by $60.0 \%$ of fucoxanthin in the pigment pool of the nanophytoplankton, and $56 \%$ of the total abundance was represented by this class. Fractioning did not allow us to assess the chemotaxonomic diversity of microphytoplankton in the oligotrophic lagoon, probably due to an insufficient pigment concentration.
Table 2. Specific growth rates $\left(\mu_{0}\right)$ and grazing rate $(g)$ measured in incubations without enrichment and maximum specific growth rates $\left(\mu_{\max }\right)$ subsequently calculated using complete enrichment in the oligo- (AYR), meso- (IN) and hypertrophic (MW) lagoons (see Fig. 1) and for total phytoplankton and micro-, nano- and ultraphytoplankton fractions. Values were estimated according the linear Landry \& Hassett (1982) equation. This model was compared to alternative models by mixed-effect multiple linear regressions of apparent growth rates, based on chl a concentration from dilution experiments. The parsimony of the different models was checked by the corrected Akaike's information criterion $\left(\mathrm{AIC}_{\mathrm{c}}\right)$. The linear model was only accepted when it presented a $\Delta \mathrm{AIC}_{\mathrm{c}}<2$ with respect to the most parsimonious model (see Section 2). $\mathrm{AIC}_{\mathrm{c}}-\mathrm{W}$ describes the strength of explanation of the model. -: no coefficient

\begin{tabular}{|c|c|c|c|c|c|c|c|c|}
\hline \multirow[t]{2}{*}{ Lagoon } & \multirow[t]{2}{*}{ Fraction } & \multicolumn{3}{|c|}{ Rates $\left(\mathrm{d}^{-1}\right)$} & \multirow[t]{2}{*}{$\mathrm{n}$} & \multirow[t]{2}{*}{$\mathrm{AIC}_{\mathrm{c}}$} & \multirow{2}{*}{$\Delta \mathrm{AIC}_{\mathrm{c}}$} & \multirow[t]{2}{*}{$\mathrm{AIC}_{\mathrm{C}}-\mathrm{W}$} \\
\hline & & $\mu_{0}$ & $g$ & $\mu_{\max }$ & & & & \\
\hline \multirow[t]{4}{*}{ AYR } & Total & 1.20 & 0.00 & 1.29 & 8 & 4.2 & 0.0 & 0.68 \\
\hline & Micro & 3.95 & 1.38 & 4.41 & 7 & 15.2 & 0.0 & 0.65 \\
\hline & Nano & - & - & - & 8 & 15.0 & 5.6 & 0.05 \\
\hline & Ultra & 1.14 & 0.46 & 1.28 & 10 & 5.9 & 0.0 & 0.43 \\
\hline \multirow[t]{4}{*}{ IN } & Total & $-0.18^{\mathrm{a}}$ & 0.22 & 0.43 & 10 & -8.6 & 0.0 & 0.41 \\
\hline & Micro & 1.22 & 0.48 & 1.83 & 8 & 7.4 & 0.3 & 0.34 \\
\hline & Nano & - & - & - & 10 & 25.2 & 4.3 & 0.09 \\
\hline & Ultra & $-0.02^{\mathrm{a}}$ & 0.35 & 0.61 & 9 & 1.8 & 0.1 & 0.34 \\
\hline \multirow[t]{4}{*}{ MW } & Total & - & - & - & 10 & 0.3 & 6.3 & 0.04 \\
\hline & Micro & 2.16 & 2.10 & 1.34 & 10 & 29.2 & 0.0 & 0.71 \\
\hline & Nano & - & - & - & 10 & 27.6 & 3.0 & 0.16 \\
\hline & Ultra & 0.91 & 1.17 & 1.14 & 10 & 0.0 & 0.0 & 0.86 \\
\hline
\end{tabular}


was mainly composed of PC-cyan (Fig. 4), exhibited a lower $\mu_{0}\left(1.14 \mathrm{~d}^{-1}\right)$, close to that of its total phytoplankton community (Table 2). In the mesotrophic lagoon, the highly diverse microphytoplankton community displayed a $\mu_{0}$ of $1.22 \mathrm{~d}^{-1}$, while the ultraphytoplankton, which dominated the community and was mainly composed of Peuk, exhibited a $\mu_{0}$ close to 0 , indicating a growth limitation. In the hypertrophic lagoon, the microphytoplankton, which was mostly composed of green algae and dinophytes, showed a high growth rate $\left(\mu_{0}=2.16 \mathrm{~d}^{-1}\right)$, while the ultraphytoplankton, which dominated the community and was mainly composed of Chlorella-like cells, exhibited a $\mu_{0}<1 \mathrm{~d}^{-1}$.

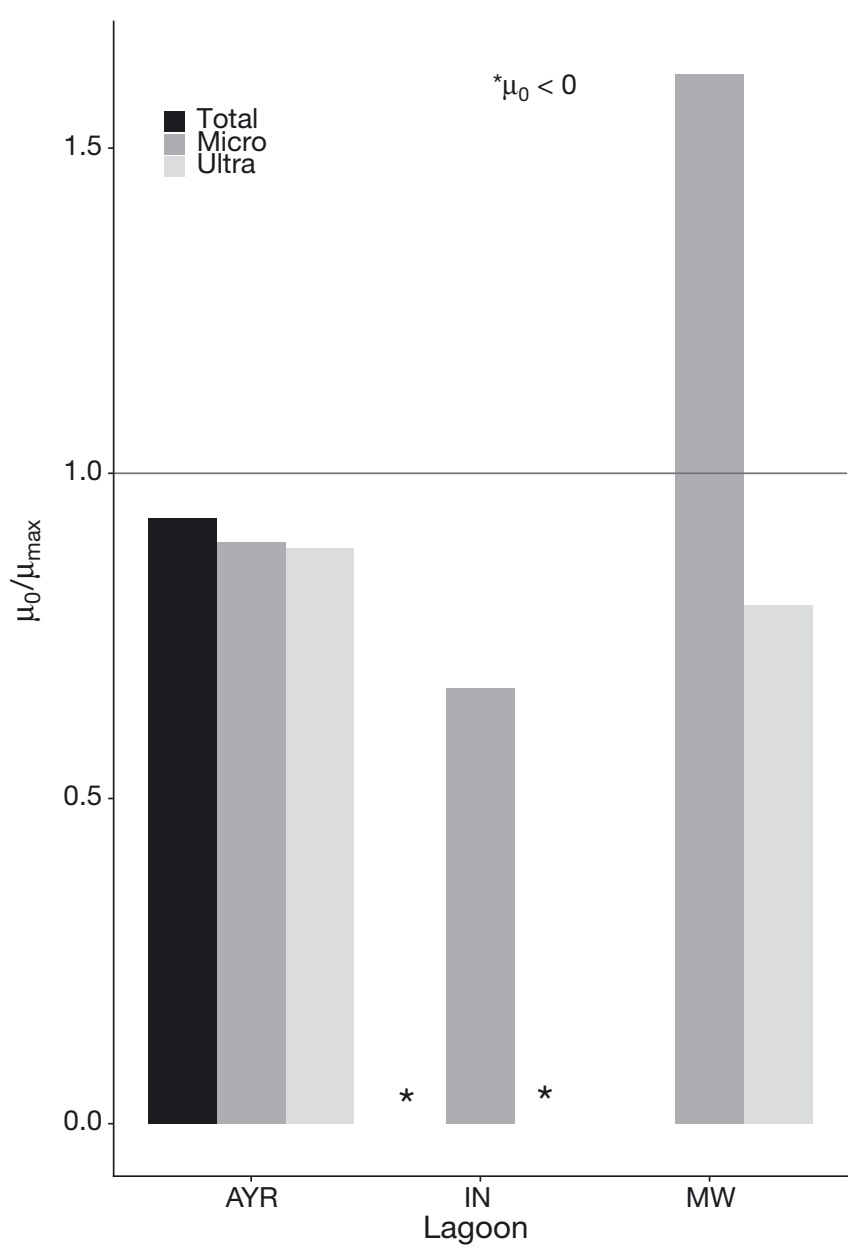

Fig. 5. Ratio between growth without enrichment and maximal growth rate with total enrichment $\left(\mu_{0}: \mu_{\max }\right)$ of total phytoplankton (black), micro- (grey) and ultraphytoplankton (light grey), in the oligo- (AYR), meso- (IN) and hypertrophic (MW), lagoons (see Fig. 1), based on growth rates calculated from chl a concentrations in summer 2014. Horizontal line highlights $\mu_{0}: \mu_{\max }$ ratio $=1$, meaning there was no change in growth rate with the full enrichment. Asterisks indicate when $\mu_{0}<0$, leading to a negative $\mu_{0}: \mu_{\max }$ ratio

\subsection{Impact of the nutrient enrichment on growth rate and limitation}

The addition of complete enrichment before the incubation resulted in an increased growth rate, except for the microphytoplankton of the hypertrophic lagoon, which decreased by $36 \%$ (Table 2). Nevertheless, in the hypertrophic lagoon, the ultraphytoplankton growth rate increased by $25.3 \%$. In the mesotrophic lagoon, the enrichment released the growth limitation, allowing a positive $\mu_{\text {max }}$. The microphytoplankton growth rate increased by $50 \%$ with the addition of the enrichment. In the oligotrophic lagoon, the enrichment allowed an increase of $7.5 \%$ of the growth rate for the total phytoplankton, $11.6 \%$ for the microphytoplankton and $12.2 \%$ for the ultraphytoplankton.

The ratio of $\mu_{0}: \mu_{\max }$ can be an index of the severity of nutrient limitation under natural conditions (Fig. 5). Hence, the total community and the ultraphytoplankton of the mesotrophic lagoon were strongly limited, as reflected by $\mu_{0}: \mu_{\max }$ ratios $<0$. A moderate limitation was observed for the microphytoplankton of the mesotrophic lagoon $\left(0.5<\mu_{0}\right.$ : $\left.\mu_{\max }=0.67<0.75\right)$. A minor degree of nutrient limitation was detected for the total, the micro- and the ultraphytoplankton of the oligotrophic lagoon and for the ultraphytoplankton of the hypertrophic lagoon $\left(\mu_{0}: \mu_{\max }>0.75\right)$. The total phytoplankton of the hypertrophic lagoon was also limited, as suggested by the non-linear trend of the relationship between the apparent growth rate and the dilution factor (Fig. S1C).

\section{5. $\mathbf{N}$ and $P$ limitation and resource exploitation during experimentally induced $\mathbf{N}$ and $\mathbf{P}$ limitation}

The growth rates of the total phytoplankton and the size classes under experimentally induced $\mathrm{N}$ and $P$ limitations are presented in Table 3 , as well as the $Q_{\mathrm{N}}$ and the $Q_{\mathrm{P}}$ ratios illustrating the severity of these limitations.

The total phytoplankton, the micro- and the ultraphytoplankton of the 3 lagoons most often exhibited nitrogen limitation, expressed by $\mu_{-\mathrm{N}}$ lower than $\mu_{\text {max }}$ leading to $Q_{\mathrm{N}}$ values $<1$ (Table 3, Fig. 6A). More particularly, in the oligotrophic lagoon, after $24 \mathrm{~h}$ incubation with the enrichment minus $\mathrm{N}$, we were not able to detect microphytoplankton biomass and were thus unable to calculate a $\mu_{-\mathrm{N}}$ value, suggesting a sharp $\mathrm{N}$ limitation for this fraction. The ultraphytoplankton in the hypertrophic lagoon showed a strong $\mathrm{N}$ limitation $\left(Q_{\mathrm{N}}=0\right.$, Fig. $\left.6 \mathrm{~A}\right)$. 
Table 3. Maximum growth rates with complete enrichment $\left(\mu_{\max }\right)$, with enrichment but without $\mathrm{N}\left(\mu_{-\mathrm{N}}\right)$ or without $\mathrm{P}\left(\mu_{-\mathrm{P}}\right)$, and $Q_{\mathrm{N}}$ and $Q_{\mathrm{P}}$ values (see Section 2.4) based on $\mu_{\max }$ and $\mu_{-\mathrm{N}}$ or $\mu_{\text {-p }}$ ratios respectively, for the oligo- (AYR), meso- (IN) and hypertrophic (MW) lagoons (see Fig. 1) and for total phytoplankton, micro-, nano- and ultraphytoplankton. -: data missing or not measurable

\begin{tabular}{|c|c|c|c|c|c|c|}
\hline \multirow[t]{2}{*}{ Lagoon } & \multirow[t]{2}{*}{ Fraction } & \multicolumn{3}{|c|}{ Rates $\left(\mathrm{d}^{-1}\right)$} & \multirow[t]{2}{*}{$Q_{\mathrm{N}}$} & \multirow[t]{2}{*}{$Q_{\mathrm{P}}$} \\
\hline & & $\mu_{\max }$ & $\mu_{-\mathrm{N}}$ & $\mu_{-P}$ & & \\
\hline \multirow[t]{4}{*}{ AYR } & Total & 1.29 & -1.06 & 0.76 & - & 0.53 \\
\hline & Micro & 4.41 & - & 1.54 & - & 0.38 \\
\hline & Nano & - & 1.48 & 1.18 & - & - \\
\hline & Ultra & 1.28 & 0.91 & 1.13 & 0.70 & 0.88 \\
\hline \multirow[t]{4}{*}{ IN } & Total & 0.43 & 0.21 & 0.26 & 0.48 & 0.59 \\
\hline & Micro & 1.83 & 0.66 & 1.52 & 0.36 & 0.83 \\
\hline & Nano & - & 0.20 & -0.08 & - & - \\
\hline & Ultra & 0.61 & 0.16 & 0.13 & 0.27 & 0.21 \\
\hline \multirow[t]{4}{*}{ MW } & Total & - & -0.01 & 1.25 & - & - \\
\hline & Micro & 1.34 & -0.21 & 2.10 & - & 1.57 \\
\hline & Nano & - & 0.85 & 1.35 & - & - \\
\hline & Ultra & 1.14 & 0.00 & 1.13 & 0.00 & 0.99 \\
\hline
\end{tabular}

The total phytoplankton of the oligo- and the mesotrophic lagoons also exhibited a $\mathrm{P}$ limitation, illustrated by $Q_{\mathrm{P}}$ values $<1$. The P limitation increased with decreasing eutrophication for the micro- and the dominant ultraphytoplankton in the 3 lagoons (Fig. 6B). The micro- and ultraphytoplankton of the hypertrophic lagoon were not P-limited $\left(Q_{\mathrm{p}}>1\right)$. In summary, along the studied eutrophication gradient, limitations varied from a co-limitation by $\mathrm{N}$ and $\mathrm{P}$ in the oligotrophic and the mesotrophic lagoons to a single and strong $\mathrm{N}$ limitation in the hypertrophic lagoon (Fig. 6B).

To cope with the experimentally induced nitrogen limitation, the total phytoplankton of the 3 lagoons differently used the 3 considered N pools (Fig. 7A,C, Table S1). In the hypertrophic lagoon, phytoplankton mainly used recycled $\mathrm{N}$, while in the mesotrophic lagoon phytoplankton mainly used the internal pool and $18 \%$ of external $\mathrm{N}$ (Fig. $7 \mathrm{~A}$ ). The size class decomposition specified different trends across the communities (Fig. 7C). In the hypertrophic lagoon, the dominant ultraphytoplankton exhibited an exclusive use of the recycled pool, while the 2 other size classes only used the internal $\mathrm{N}$ pool (Fig. 7C). In the mesotrophic lagoon, the $\mathrm{N}$ use of the 2 main size classes echoed the total phytoplankton: ultraphytoplankton used internal resources and nanophytoplankton used the external one. The microphytoplankton used $84 \%$ of recycled $\mathrm{N}$ and $16 \%$ of internal $\mathrm{N}$ pools. In the oligotrophic lagoon, the ultraand nanophytoplankton used internal $\mathrm{N}$ resources.
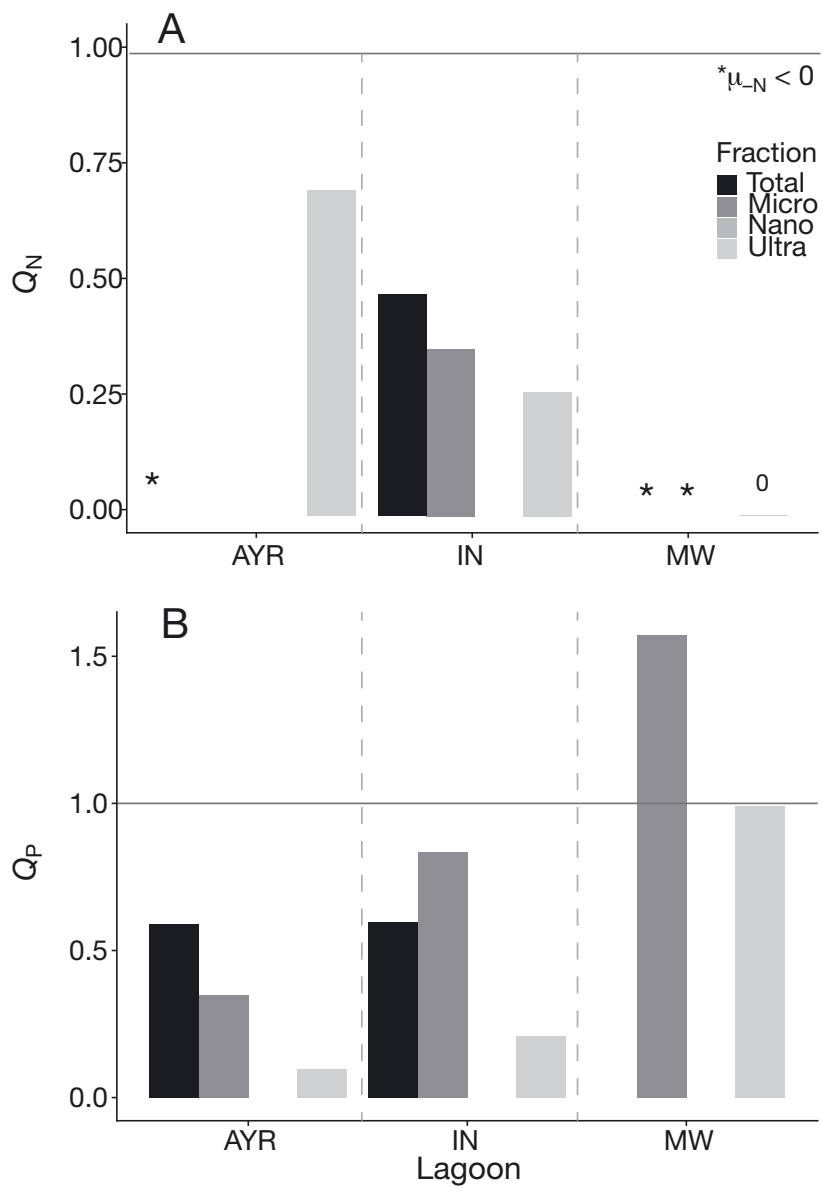

Fig. 6. Ratio between maximal growth rates with total enrichment and enrichment $(\mathrm{A})$ without $\mathrm{N}\left(Q_{\mathrm{N}}\right)$ and $(\mathrm{B})$ without $\mathrm{P}\left(Q_{\mathrm{P}}\right)$ for total phytoplankton (black) and micro- (dark grey) and ultraphytoplankton (light grey), in the oligo- (AYR), meso(IN) and hypertrophic (MW) lagoons (see Fig. 1), based on growth rates calculated from chl a concentrations in summer 2014. Lagoons separated by dashed vertical lines. The horizontal line highlights ratios equal to 1 , meaning there was no change in growth rate with the enrichments minus $\mathrm{N}$ or minus P. Asterisks indicate when $\mu_{-\mathrm{N}}$ were $<0$,leading to negative $Q_{\mathrm{N}}$ or $Q_{\mathrm{P}}$

To cope with the experimentally induced phosphorus limitation, the total phytoplankton in the 3 lagoons used the 3 different $\mathrm{P}$ pools (Fig. 7B,D, Table S1). Phytoplankton mainly used $67 \%$ of internal and $33 \%$ of recycled $P$ loads in the oligotrophic lagoon (Fig. 7B); $91 \%$ of recycled $\mathrm{P}$ and $9 \%$ of external $\mathrm{P}$ loads in the mesotrophic lagoon; and $85 \%$ of internal P and $15 \%$ of external P loads in the hypertrophic lagoon. The decomposition in size classes highlights several strategies of P use (Fig. 7D). In the oligotrophic lagoon, the microphytoplankton only used recycled $\mathrm{P}$, while the nano- and ultraphytoplankton only used internal P loads. In the mesotrophic lagoon, the microphytoplankton used $90 \%$ of recycled $\mathrm{P}$ and $5 \%$ of external and internal loads, 


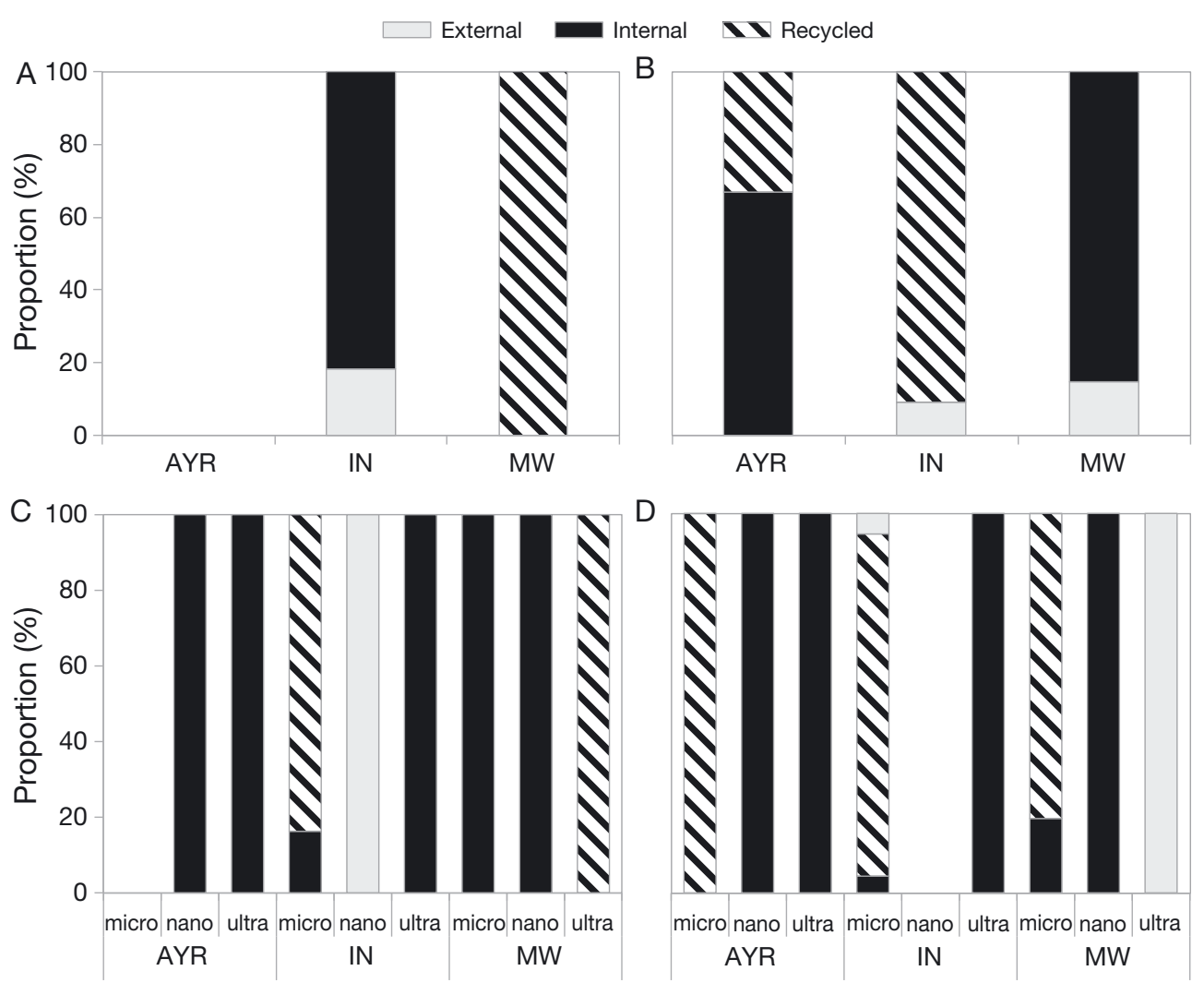

Fig. 7. Contribution of internal (black), external (light gray) and recycled (hatched) (A,C) nitrogen and (B,D) phosphorus resources used for growth under limited condition, for total phytoplankton (A,B), and decomposed for micro-, nano- and ultraphytoplankton (C,D) in oligo- (AYR), meso- (IN) and hypertrophic (MW) lagoons (see Fig. 1) during summer 2014. Negative values of $K$ coefficients have not been taken into account

while the ultraphytoplankton only used internal $\mathrm{P}$ loads. In the hypertrophic lagoon, external P loads were exclusively used by the ultraphytoplankton. The microphytoplankton used $80 \%$ of recycled and $20 \%$ of internal $\mathrm{P}$, and the nanophytoplankton exclusively used internal P loads.

\section{DISCUSSION}

\subsection{Phytoplankton community composition related to different eutrophication status}

In this paper, we describe the phytoplankton communities of 3 contrasting lagoons sampled in summer 2014 , and discuss how their adaptive strategies of nutrient use can be linked with the characteristics of the lagoons, especially their eutrophication status. We particularly pay attention to how the re-oligotrophication processes initiated in 2005 in the hypertrophic and mesotrophic lagoons impact these strategies.

The summer phytoplankton communities were dominated by ultraphytoplankton in all 3 lagoons. This is a characteristic feature of most Mediterranean coastal lagoons (Bec et al. 2011). Small autotrophic cells are particularly competitive in taking up nutrients due to their high nutrient affinities (Chisholm 1992, Raven 1998). Indeed, DIN concentrations were below $1.5 \mu \mathrm{M}$ in the 3 lagoons, showing the ability of these small cells to take up DIN. Ammonium dominated the DIN during summer, as it results from internal recycling and benthic fluxes (Collos et al. 2003, Ouisse et al. 2013). Both cell counts and biomasses showed that Peuk mainly comprising Chlorella-like cells dominated the ultraphytoplankton of the hypertrophic lagoon. Among the green algae, prasinophytes and chlorophytes observed in this lagoon both possess a good tolerance to high $\mathrm{NH}_{4}$ concentrations, as well as a high affinity for uptake (Bec et al. 2011). In addition, these organisms are also well adapted to turbulence, turbidity and variable salinity (Paerl et al. 2007), as observed in the hypertrophic lagoon (Leruste et al. 2018). Moreover, their high photosynthetic efficiency also confers a competitive advantage (Raven 1998, Litchman et al. 2010), which may explain their success in this turbid system (Bec et al. 2005, 2008, 2011). 
The abundance of heterotrophic dinophytes in the hypertrophic lagoon can be linked to their competitive advantage in acquiring nutrients in systems displaying important stocks of organic matter and low dissolved inorganic nutrient concentrations. Indeed, when dissolved inorganic nutrients are depleted or when there is a strong competition for nutrients, mixotrophic or strictly heterotrophic species can use alternative nutrient resources and have high growth efficiency (Litchman et al. 2006). Moreover, compared to strict autotrophs and heterotrophs, mixotrophs are more successful under $\mathrm{N}$ limitation, because of their higher growth efficiency when consuming N-starved prey (Fischer et al. 2017). For example, in the nearby Thau lagoon, dinophytes, comprising mixotrophic and heterotrophic species blooming under $\mathrm{N}$ limitation during dry periods, and some mixotrophic species consumed dissolved organic nitrogen (Collos et al. 2014). Moreover, several dinophyte species, such as Gyrodinium sp. and Protoperidinium sp. observed in the hypertrophic and the mesotrophic lagoons, have demonstrated abilities to graze on diatoms or ciliates (Legrand et al. 1998). These abilities could explain their persistence in these systems dominated by Peuk and despite the nutrient depletion (Zhang et al. 2005). Dissolved and particulate organic nutrient concentrations in the lagoon water column and sediments, and the remineralization of these nutrient stocks, were not estimated in this study, and would be very interesting to explore. Such studies would reveal more about the real availability of nutrients for the potentially mixotrophic and heterotrophic species we observed in this study.

In the oligotrophic lagoon, cell counts showed that picocyanobacteria were more abundant than Peuk, while Peuk biomass dominated over picocyanobacteria. This apparent contradiction can be explained by the larger size of Peuk (1-3 $\mu \mathrm{m})$ than picocyanobacteria $(\leq 1 \mu \mathrm{m})$. Hence, picocyanobacteria represented a lower biomass, but were still able to outnumber Peuk in this oligotrophic system because of their small cell size. Picoyanobacteria in both oligotrophic and hypertrophic lagoons were dominated by PC-cyan, which contrasted with the mesotrophic lagoon where picocyanobacteria were dominated by PE-cyan. PC-cyan efficiently use red light, which dominates the spectrum in turbid waters with high plankton densities or high sediment re-suspension. Hence, their presence in the oligotrophic lagoon appears to be linked to turbidity due to recurrent sedimentary suspension affecting the water column light quality (Stomp et al. 2007). Conversely, the presence of PE-cyan in the meso- trophic lagoon reflected an adaptation to low turbidity (Vörös et al. 1998).

Without enrichment, the highest calculated specific growth rates were 3.95 and $2.16 \mathrm{~d}^{-1}$ for the microphytoplankton in the oligo- and hypertrophic lagoons, respectively. In the oligotrophic lagoon, this size fraction was mainly composed of diatoms, which have already shown high growth rates in Mediterranean lagoons (Bec et al. 2005). The microphytoplankton of the hypertrophic lagoon in this sampling was mainly composed of mixo- or heterotrophic dinophytes that displayed competitive advantages in coping with the nutrient limitation.

\subsection{Phytoplankton nutrient limitation}

During the summer season, nutrient pulses in the lagoons are scarce, and nutrients can be rapidly depleted, depending on the sediment stocks. Nutrient limitation impacts phytoplankton biomass, community composition in terms of functional groups, and growth (Domingues et al. 2011). The TN:TP ratio, which is a proxy for elemental ratios in phytoplankton, provided a first insight into the nutrients limiting their growth (Ptacnik et al. 2010, Souchu et al. 2010). This ratio was higher than the Redfield ratio for the oligo- and mesotrophic lagoons, and slightly lower for the hypertrophic lagoon. This suggests that phosphorus was the limiting factor in the oligo- and mesotrophic lagoons, while nitrogen was the limiting factor in the hypertrophic lagoon, which is in agreement with earlier observations of a shift from phosphorus to nitrogen limitation with increasing eutrophication (Souchu et al. 2010). The high dissolved inorganic phosphorus concentration in the hypertrophic lagoon further supports the notion that phosphate was not limiting.

The 'All minus one' experiments give further indications about in situ growth-limiting factors. Indeed, nitrogen limitation in the hypertrophic lagoon was reflected by $Q_{\mathrm{N}}$ and $Q_{\mathrm{P}}$ values (0 and 1 ). In contrast, in the oligotrophic and mesotrophic lagoons, $Q_{\mathrm{N}}$ and $Q_{\mathrm{P}}$ values consistently below 1 indicate the ease of inducing $\mathrm{N}$ and $\mathrm{P}$ limitation in experimental incubations. This raises the question of whether phytoplankton in these lagoons was co-limited by $\mathrm{N}$ and $\mathrm{P}$ simultaneously. Although this is in principle in contradiction with Liebig's 'law of the minimum' (von Liebig 1840), there is increasing evidence of $\mathrm{N}$ and $\mathrm{P}$ co-limitation in freshwater, marine and coastal ecosystems (Sakka Hlaili et al. 2006, Elser et al. 2007, Harpole et al. 2011). Such co-limitation is consistent 
with both low DIN and DIP concentrations in the oligotrophic and mesotrophic lagoons. Moreover, a more gradual shift from $\mathrm{P}$ limitation via $\mathrm{N}$ and $\mathrm{P}$ co-limitation to an exclusive $\mathrm{N}$ limitation between lagoons with increasing eutrophication has already been demonstrated (Souchu et al. 2010). Among the co-limitation, different size classes expressed some specificities according to their composition, their affinity with nutrients determining their uptake efficiency and the amount of available nutrients. For example, in the oligotrophic lagoon, PC-cyan were more $\mathrm{N}$ - than P-limited, probably because of their high affinity for $\mathrm{P}$ due to specific mechanisms of acquiring this nutrient (Donald et al. 1997). To sustain their growth under limitation, phytoplankton used other resources in addition to those externally supplied. For example, in the hypertrophic lagoon, the dominant ultraphytoplankton was the most competitive because it used recycled $\mathrm{N}$ and external P. In this lagoon, the nanophytoplankton used internal $\mathrm{N}$ and P pools, while the microphytoplankton predominantly used recycled $P$.

\subsection{Reactivity of phytoplankton to nutrient pulses}

To better understand phytoplankton adaptations to environmental changes during the re-oligotrophication process, it is necessary to assess the sensibility and the responsiveness of these communities to a nutrient pulse (Duarte et al. 2000, Wood \& Bukaveckas 2014). We assume that re-oligotrophication, which reduces nutrient availability, results in an increase in the nutrient limitation for phytoplankton communities. Moreover, the nutrient requirement is expected to increase with increasing eutrophication (Domingues et al. 2015). Eutrophication has the greatest impact on ecosystem functioning in Mediterranean lagoons during summer, when temperature and irradiance are optimal (1) for the growth of autotrophic organisms, and (2) for the recycling of nutrients from the sediment (Collos et al. 2003). In most cases where we were able to calculate specific growth and grazing rates, nutrient enrichment enhanced growth rates, reflecting the nutrient limitation occurring in summer. The only exception was for the microphytoplankton of the hypertrophic lagoon, for which we observed an unlikely ratio of $\mu_{0}: \mu_{\max }=$ 1.6, which was probably due to an underestimation of $\mu_{\max }$. Hence, despite the high concentration of added nutrients $(20 \mu \mathrm{M}$ final concentration of nitrogen), the enrichment was insufficient to allow a linear trend of the total phytoplankton apparent growth rate as a function of the dilution factor (Fig. S1C) (Landry \& Hassett 1982). Most likely, the very high phytoplankton biomass resulted in a nutrient depletion for the less diluted samples and consequently in an underestimation of their specific growth rates. This was supported by the very low apparent growth rate in the bottles containing 100 and $75 \%$ of unfiltered water.

In the oligotrophic lagoon, the nutrient pulse only marginally stimulated the phytoplankton growth rate (less than $12 \%$ ) compared to the response of the communities of both lagoons (IN and MW) from the Palavas complex. This may reflect a luxury consumption of $\mathrm{N}$ and $\mathrm{P}$, which is a common strategy used by phytoplankton to deal with variable nutrient variability. Cells use nutrient enrichment to build up an intracellular storage that can later be used for growth after the depletion of the external nutrient supply (Domingues et al. 2015). Several phytoplanktonic groups commonly use these strategies. For example, many diatoms use storage (Litchman et al. 2007, Domingues et al. 2011), and several picophytoplanktonic species use luxury consumption in variable nutrient regimes (Glover et al. 2007). The phytoplankton of the mesotrophic lagoon responded most to the enrichment, showing the highest increase $(50 \%)$ in growth rates of microphytoplankton. This result highlights that the re-oligotrophication trajectory of this lagoon is still very vulnerable to occasional eutrophication events. The ultraphytoplankton of the hypertrophic lagoon also responded to the enrichment by an increase in its growth rate. However, this increase was lower than that of the phytoplankton of the mesotrophic lagoon. Considering the high phytoplankton biomass and abundances in the hypertrophic lagoon, the enrichment was insufficient to satisfy their nutrient requirement and allow the estimation of their maximal growth rate.

\subsection{Vulnerability of lagoons to nutrient pulses during re-oligotrophication}

Our experiments may provide some indications whether an incidental nutrient pulse impacts phytoplankton communities, suggesting a vulnerability of the lagoon to eutrophication, even during a re-oligotrophication process. In the mesotrophic lagoon, the micro- and ultraphytoplankton size classes quickly reacted to the enrichment, showing that they are highly sensitive to a nutrient pulse. Among the phytoplankton and the macrophytic communities in this lagoon, Peuk always seem to be the most reac- 
tive to a nutrient pulse. This highlights the fragility of the re-oligotrophication process during the summer period, even in a relatively less degraded lagoon compared to other eutrophicated systems.

Despite the $9 \mathrm{yr}$ of re-oligotrophication, the hypertrophic lagoon still presented eutrophic characteristics, and was still dominated by picophytoplankton (Bec et al. 2011), which was the main group reacting to the nutrient pulse; within this group, Chlorellalike cells were particularly reactive. These cells are highly competitive in turbulent systems, during summer, and when DIN supply is dominated by ammonium (Margalef 1978, Reynolds \& Lund 1988, Litchman et al. 2007). However, the enhancement of the ultraphytoplankton growth by the enrichment was attenuated by the particularly high phytoplankton biomasses observed in August 2014. Indeed, the chl a concentration mainly stemming from Peuk reached $36 \mu \mathrm{g} \mathrm{l}^{-1}$. This high biomass was much higher than that observed during the preceding summer periods (median chl a concentrations of $3.68 \mu \mathrm{g} \mathrm{l}^{-1}$ between June and August from 2007 to 2013). This was the first return to levels (mean $\pm \mathrm{SD}$ ) observed at the beginning of the re-oligotrophication process in summer $2006\left(79.9 \pm 40.7 \mu \mathrm{g} \mathrm{chl} \mathrm{a}{ }^{-1}\right.$, Leruste et al. 2016). Such density may reflect the lagoon's vulnerability and potential inertia to the re-oligotrophication, due to occasional nutrient inputs and recurrent internal loads sustained by benthic fluxes (Phillips et al. 2005). These fluxes of ammonium and phosphate are particularly important during summer (Collos et al. 2003, Ouisse et al. 2013), and were partly reflected by the high phosphate concentration $(2.48 \mu \mathrm{M})$. This release impacts benthic and pelagic communities, particularly in shallow systems with less than $5 \mathrm{~m}$ depth, such as most coastal lagoons (Cowan et al. 1996). Hence, this may have enhanced Peuk and PCcyan growth (Velasco et al. 2006), leading to their bloom (Carstensen et al. 2007).

In contrast, in the oligotrophic lagoon, the very low biomass and the numerical dominance of PC-cyan reflect an adaptation to the oligotrophic conditions (Caroppo 2000). Compared to those of the other lagoons, the community of Ayrolle was slightly enhanced by the nutrient enrichment. In this respect, the $\mu_{0}$ values were surprisingly high both for the micro- and the ultraphytoplankton. Moreover, these were only partly compensated by the measured grazing rates. In this shallow oligotrophic lagoon, the ecosystem functioning is largely impacted by the benthos. An important cover of seagrasses (Zostera noltei, $>80 \%$ of coverage) predominates the primary production and inorganic nutrient uptake (De Wit et al. 2017). In addition, the benthos is home to suspension feeders that exert grazing pressure on phytoplankton, maintaining low population densities despite high $\mu_{0}$ values. Thus, benthic and macrophytic communities mainly benefit from nutrient input (Bricker et al. 2008). The phytoplankton may have adapted by using other nutrient sources, such as internal pools, to cope with this low access to nutrient loads (Glover et al. 2007). We expect that the short-term vulnerability of the currently meso- and hypertrophic lagoons will only decrease after prolonged re-oligotrophication, and particularly upon return of the benthic communities that are characteristic for the oligotrophic conditions, such as the marine Magnoliophyta.

Acknowledgements. A.L. was supported by a PhD fellowship from the French Ministry of Education, Higher Education and Scientific Research granted by the Doctoral School GAIA in Montpellier. This study received partial funding from the French Agence Nationale de la Recherche through its Labex 'Dispositif de Recherche Interdisciplinaire pour les Interactions Hommes-Milieux (DRIIHM)', program 'OHM Littoral méditterranéen'. We thank the anonymous reviewers for their helpful comments, and Sébastien Mas and David Parin from the Station Marine de Sète OSU OREME, for technical support and help during the experiments. We also thank the Microbex platform of the MARBEC UMR that provided microscopy and imaging equipment, and particularly Cécile Roques, who provided technical support for microscopic analyses. Thanks are extended to everyone who participated in the experiments. This paper is dedicated to the memory of Yves Collos (1949-2015).

\section{LITERATURE CITED}

Aminot A, Kérouel R (2004) Hydrologie des écosystèmes marins. Paramètres et analyses. Ifremer Editions, Plouzané

Aminot A, Kérouel R (2007) Dosage automatique des nutriments dans les eaux marines: méthodes en flux continu. Ifremer,

Andersen T, Schartau AKL, Paasche E (1991) Quantifying external and internal nitrogen and phosphorus pools, as well as nitrogen and phosphorus supplied through remineralization, in coastal marine plankton by means of a dilution technique. Mar Ecol Prog Ser 69:67-80

Bartón K (2013) MuMIn: Multi-model inference. Model selection and model averaging based on information criteria (AICc and alike). http://cran.r-project.org/web/packages/ MuMIn/index.html

Bates D, Mächler M, Bolker B, Walker S (2015) Fitting linear mixed-effects models using lme4. J Stat Softw 67:1-48

* Bec B, Husseini-Ratrema J, Collos Y, Souchu P, Vaquer A (2005) Phytoplankton seasonal dynamics in a Mediterranean coastal lagoon: emphasis on the picoeukaryote community. J Plankton Res 27:881-894

Bec B, Collos Y, Vaquer A, Mouillot D, Souchu P (2008) Growth rate peaks at intermediate cell size in marine photosynthetic picoeukaryotes. Limnol Oceanogr 53:863-867

* Bec B, Collos Y, Souchu P, Vaquer A and others (2011) Dis- 
tribution of picophytoplankton and nanophytoplankton along an anthropogenic eutrophication gradient in French Mediterranean coastal lagoons. Aquat Microb Ecol 63:29-45

Bricker SB, Longstaf B, Dennison W, Jones A, Boicourt K, Wicks C, Woerner J (2008) Effects of nutrient enrichment in the nation's estuaries: a decade of change. Harmful Algae 8:21-32

Burnham KP, Anderson DR (eds) (2004) Model selection and multimodel inference. Springer, New York, NY

Caroppo C (2000) The contribution of picophytoplankton to community structure in a Mediterranean brackish environment. J Plankton Res 22:381-397

Carstensen J, Henriksen P, Heiskanen AS (2007) Summer algal blooms in shallow estuaries: definition, mechanisms, and link to eutrophication. Limnol Oceanogr 52:370-384

Cartaxana P, Mendes CR, Brotas V (2009) Phytoplankton and ecological assessment of brackish and freshwater coastal lagoons in the Algarve, Portugal. Lakes Reserv Res Manag 14:221-230

Chisholm SW (1992) Phytoplankton size. In: Falkowski PG, Woodhead AD, Vivirito K (eds) Primary productivity and biogeochemical cycles in the sea. Springer, Cambridge, MA, p 213-237

Cloern JE (2001) Our evolving conceptual model of the coastal eutrophication problem. Mar Ecol Prog Ser 210:223-253

Collos Y, Vaquer A, Bibent B, Souchu P, Slawyk G, Garcia N (2003) Response of coastal phytoplankton to ammonium and nitrate pulses: seasonal variations of nitrogen uptake and regeneration. Aquat Ecol 37:227-236

Collos Y, Gagne C, Laabir M, Vaquer A, Cecchi P, Souchu P (2004) Nitrogenous nutrition of Alexandrium catenella (Dinophyceae) in cultures and in Thau Lagoon, Southern France. J Phycol 40:96-103

Collos Y, Bec B, Jauzein C, Abadie E and others (2009) Oligotrophication and emergence of picocyanobacteria and a toxic dinoflagellate in Thau lagoon, southern France. J Sea Res 61:68-75

Collos Y, Jauzein C, Ratmaya W, Souchu P, Abadie E, Vaguer A (2014) Comparing diatom and Alexandrium catenella/tamarense blooms in Thau lagoon: importance of dissolved organic nitrogen in seasonally N-limited systems. Harmful Algae 37:84-91

Cowan JLW, Pennock JR, Boynton WR (1996) Seasonal and interannual patterns of sediment-water nutrient and oxygen fluxes in Mobile Bay, Alabama (USA): regulating factors and ecological significance. Mar Ecol Prog Ser 141:229-245

Crossetti LO, Bicudo CED (2005) Structural and functional phytoplankton responses to nutrient impoverishment in mesocosms placed in a shallow eutrophic reservoir (Garcas Pond), Sao Paulo, Brazil. Hydrobiologia 541:71-85

De Jonge VN, de Jong DJ (2002) Ecological restoration in coastal areas in the Netherlands: concepts, dilemmas and some examples. Hydrobiologia 478:7-28

De Jonge VN, Elliott M (2001) Eutrophication. Encycl Ocean Sci 2:852-870

* De Wit R, Rey-Valette H, Balavoine J, Ouisse V, Lifran R (2017) Ecological restoration of coastal lagoons; prediction of ecological trajectories and economic valuation. Aquat Conserv 27:137-157

* Domingues RB, Barbosa AB, Sommer U, Galvao HM (2011) Ammonium, nitrate and phytoplankton interactions in a freshwater tidal estuarine zone: potential effects of cultural eutrophication. Aquat Sci 73:331-343
Domingues RB, Guerra CC, Barbosa AB, Galvao HM (2015) Are nutrients and light limiting summer phytoplankton in a temperate coastal lagoon? Aquat Ecol 49:127-146

* Donald KM, Scanlan DJ, Carr NG, Mann NH, Joint I (1997) Comparative phosphorus nutrition of the marine cyanobacterium Synechococcus WH7803 and the marine diatom Thalassiosira weissflogii. J Plankton Res 19: 1793-1813

* Duarte CM, Agusti S, Gasol JM, Vaqué D, VazquezDominguez E (2000) Effect of nutrient supply on the biomass structure of planktonic communities: an experimental test on a Mediterranean coastal community. Mar Ecol Prog Ser 206:87-95

Elser JJ, Bracken MES, Cleland EE, Gruner DS and others (2007) Global analysis of nitrogen and phosphorus limitation of primary producers in freshwater, marine and terrestrial ecosystems. Ecol Lett 10:1135-1142

Fischer R, Giebel HA, Ptacnik R (2017) Identity of the limiting nutrient ( $\mathrm{N}$ vs. P) affects the competitive success of mixotrophs. Mar Ecol Prog Ser 563:51-63

*Gallegos CL (2014) Long-term variations in primary production in a eutrophic sub-estuary. I. Seasonal and spatial patterns. Mar Ecol Prog Ser 502:53-67

Glover HE, Garside C, Trees CC (2007) Physiological responses of Sargasso Sea picoplankton to nanomolar nitrate perturbations. J Plankton Res 29:263-274

* Guillard RRL, Ryther JH (1962) Studies of marine planktonic diatoms: I. Cyclotella nana Hustedt, and Detonula confervacea (Cleve) Gran. Can J Microbiol 8:229-239

*Harpole WS, Ngai JT, Cleland EE, Seabloom EW and others (2011) Nutrient co-limitation of primary producer communities. Ecol Lett 14:852-862

* Holmes RM, Aminot A, Kérouel R, Hooker BA, Peterson BJ (1999) A simple and precise method for measuring ammonium in marine and freshwater ecosystems. Can J Fish Aquat Sci 56:1801-1808

Ifremer (2009) Réseau de Suivi Lagunaire du LanguedocRoussillon. Bilan des résultats 2008. RST/LER/LR09.007. https://archimer.ifremer.fr/doc/00118/22922/

Jeppesen E, Søndergaard M, Jensen JP, Havens KE and others (2005) Lake responses to reduced nutrient loading - an analysis of contemporary long-term data from 35 case studies. Freshw Biol 50:1747-1771

Jeppesen E, Søndergaard M, Meerhoff M, Lauridsen TL, Jensen JP (2007) Shallow lake restoration by nutrient loading reduction-some recent findings and challenges ahead. Hydrobiologia 584:239-252

Kamenir Y, Morabito G (2009) Lago Maggiore oligotrophication as seen from the long-term evolution of its phytoplankton taxonomic size structure. J Limnol 68:146-161

* Landry M, Hassett R (1982) Estimating the grazing impact of marine micro-zooplankton. Mar Biol 67:283-288

KLandry MR, Brown SL, Campbell L, Constantinou J, Liu H (1998) Spatial patterns in phytoplankton growth and microzooplankton grazing in the Arabian Sea during monsoon forcing. Deep Sea Res II 45:2353-2368

* Legrand C, Granéli E, Carlsson P (1998) Induced phagotrophy in the photosynthetic dinoflagellate Heterocapsa triquetra. Aquat Microb Ecol 15:65-75

Leruste A, Hatey A, Bec B, De Wit R (2015) Selecting an HPLC method for chemotaxonomic analysis of phytoplankton community in Mediterranean coastal lagoons. Transit Waters Bull 9:20-41

* Leruste A, Malet N, Munaron D, Derolez V and others (2016) First steps of ecological restoration in Mediterran- 
ean lagoons: shifts in phytoplankton communities. Estuar Coast Shelf Sci 180:190-203

Leruste A, Villéger S, Malet N, Wit RD, Bec B (2018) Complementarity of the multidimensional functional and the taxonomic approaches to study phytoplankton communities in three Mediterranean coastal lagoons of different trophic status. Hydrobiologia 815:207-227

Leruste A, Pasqualini V, Garrido M, Malet N, De Wit R, Bec B (2019) Physiological and behavioral responses of phytoplankton communities to nutrient availability in a disturbed Mediterranean coastal lagoon. Estuar Coast Shelf Sci 219:176-188

Litchman E, Klausmeier CA, Miller JR, Schofield OM, Falkowski PG (2006) Multi-nutrient, multi-group model of present and future oceanic phytoplankton communities. Biogeosciences 3:585-606

Litchman E, Klausmeier CA, Schofield OM, Falkowski PG (2007) The role of functional traits and trade-offs in structuring phytoplankton communities: scaling from cellular to ecosystem level. Ecol Lett 10:1170-1181

Litchman E, de Tezanos Pinto P, Klausmeier CA, Thomas MK, Yoshiyama K (2010) Linking traits to species diversity and community structure in phytoplankton. Hydrobiologia 653:15-28

Margalef R (1978) Life-forms of phytoplankton as survival alternatives in an unstable environment. Oceanol Acta 1: 493-509

Neveux J, Lantoine F (1993) Spectrofluorometric assay of chlorophylls and phaeopigments using the least squares approximation technique. Deep Sea Res I Oceanogr Res Pap 40:1747-1765

Nixon SW (2009) Eutrophication and the macroscope. Hydrobiologia 629:5-19

Ouisse V, Fiandrino A, De Wit R, Malet N (2013) Restauration des écosystèmes lagunaires: évaluation du rôle du sédiment et des herbiers à phanérogames. IFREMER RST/ LERLR 13-09. https://archimer.ifremer.fr/doc/00166/ 27774/25964.pdf

Paerl HW, Valdes LM, Pinckney JL, Piehler MF, Dyble J, Moisander PH (2003) Phytoplankton photopigments as indicators of estuarine and coastal eutrophication. BioScience 53:953-964

Paerl HW, Valdes-Weaver LM, Joyner AR, Winkelmann V (2007) Phytoplankton indicators of ecological change in the eutrophying Pamlico Sound system, North Carolina. Ecol Appl 17:S88-S101

Pereira Coutinho MT, Brito AC, Pereira P, Goncalves AS, Moita MT (2012) A phytoplankton tool for water quality assessment in semi-enclosed coastal lagoons: open vs closed regimes. Estuar Coast Shelf Sci 110:134-146

Phillips G, Kelly A, Pitt JA, Sanderson R, Taylor E (2005) The recovery of a very shallow eutrophic lake, 20 years after the control of effluent derived phosphorus. Freshw Biol 50:1628-1638

Ptacnik R, Andersen T, Tamminen T (2010) Performance of the Redfield ratio and a family of nutrient limitation indicators as thresholds for phytoplankton N vs. P limitation. Ecosystems 13:1201-1214

R Core Team (2013) R: a language and environment for statistical computing. R Foundation for Statistical Computing, Vienna

Raimbault P, Slawyk G, Coste B, Fry J (1990) Feasibility of using an automated colorimetric procedure for the deter- mination of seawater nitrate in the 0 to $100 \mathrm{nM}$ range: examples from field and culture. Mar Biol 104:347-351

* Raven JA (1998) The twelfth Tansley Lecture. Small is beautiful: the picophytoplankton. Funct Ecol 12:503-513

Reynolds CS, Lund JWG (1988) The phytoplankton of an enriched, soft-water lake subject to intermittent hydraulic flushing (Grasmere, English Lake District). Freshw Biol 19:379-404

Roy S, Llewellyn CA, Egeland ES, Johnsen G (eds) (2011) Phytoplankton pigments: characterization, chemotaxonomy and applications in oceanography. Cambridge University Press, Cambridge

Ruggiu D, Morabito G, Panzani P, Pugnetti A (1998) Trends and relations among basic phytoplankton characteristics in the course of the long-term oligotrophication of Lake Maggiore (Italy). Hydrobiologia 369:243-257

Sakka Hlaili A, Chikhaoui MA, El Grami B, Mabrouk HH (2006) Effects of $\mathrm{N}$ and P supply on phytoplankton in Bizerte Lagoon (western Mediterranean). J Exp Mar Biol Ecol 333:79-96

Serpa D, Falcao M, Duarte P, da Fonseca LC, Vale C (2007) Evaluation of ammonium and phosphate release from intertidal and subtidal sediments of a shallow coastal lagoon (Ria Formosa - Portugal): a modelling approach. Biogeochemistry 82:291-304

Sherrard NJ, Nimmo M, Llewellyn CA (2006) Combining HPLC pigment markers and ecological similarity indices to assess phytoplankton community structure: an environmental tool for eutrophication? Sci Total Environ 361: 97-110

Souchu P, Bec B, Smith VH, Laugier T and others (2010) Patterns in nutrient limitation and chlorophyll $a$ along an anthropogenic eutrophication gradient in French Mediterranean coastal lagoons. Can J Fish Aquat Sci 67: 743-753

* Stomp M, Huisman J, Vörös L, Pick FR, Laamanen M, Haverkamp T, Stal LJ (2007) Colourful coexistence of red and green picocyanobacteria in lakes and seas. Ecol Lett 10:290-298

*Van Donk E, Hessen DO, Verschoor AM, Gulati RD (2008) Re-oligotrophication by phosphorus reduction and effects on seston quality in lakes. Limnologica 38: 189-202

Velasco J, Lloret J, Millan A, Marin A, Barahona J, Abellan P, Sanchez-Fernandez D (2006) Nutrient and particulate inputs into the Mar Menor lagoon (Se Spain) from an intensive agricultural watershed. Water Air Soil Pollut $176: 37-56$

von Liebig J (1840) Organic chemistry in its applications to agriculture and physiology. English translation by L. Playfair. Taylor and Walton, London

Vörös L, Callieri C, Balogh KV, Bertoni R (1998) Freshwater picocyanobacteria along a trophic gradient and light quality range. Hydrobiologia 369:117-125

Wood JD, Bukaveckas PA (2014) Increasing severity of phytoplankton nutrient limitation following reductions in point source inputs to the tidal freshwater segment of the James River estuary. Estuaries Coasts 37: 1188-1201

Zhang LY, Sun J, Liu DY, Yu ZS (2005) Studies on growth rate and grazing mortality rate by microzooplankton of size-fractionated phytoplankton in spring and summer in the Jiaozhou Bay, China. Acta Oceanol Sin 24:85-101 